\title{
Phylogenetic relationships among biological species of Armillaria from China
}

\author{
Martin P.A. Coetzee ${ }^{\mathrm{a}, *}$, Brenda D. Wingfield ${ }^{\mathrm{a}}$, Jun Zhao ${ }^{\mathrm{b}}$, Sophia van Coller ${ }^{\mathrm{a}}$ and \\ Michael J. Wingfield ${ }^{\mathrm{a}}$
}

${ }^{a}$ Department of Genetics, Forestry and Agricultural Institute (FABI), University of Pretoria, Pretoria, South Africa

${ }^{\mathrm{b}}$ General Station of Forest Pest Control, State Forestry Administration, Shenyang 110034, China

*Corresponding author:

MPA Coetzee

Tel: +27124204826

Fax: +27 124203960

E-mail: martin.coetzee@fabi.up.ac.za

\section{Highlights}

- Phylogenetic relationships among Armillaria species from China were determined.

- Four main phylogenetic lineages were identified for Chinese Armillaria isolates.

- Unnamed biological species from China grouped in the "A. gallica cluster".

\begin{abstract}
Fourteen Chinese Biological Species (CBS) of Armillaria were previously identified in a collection of Chinese isolates. CBS C, F, G, H, J, L, N and O remained unnamed, while the remaining isolates included A. borealis, A. cepistipes, A. gallica, A. mellea, A. sinapina and A. tabescens. CBS F was suggested to represent $A$. singula based on basidiocarp morphology. In this study, phylogenetic relationships between Chinese Armillaria isolates and those from other parts of the world were determined based on DNA sequence data. Results of this study suggest that CBS F might not represent $A$. singula, and that $A$. monadelpha (a name applied to the North American form of $A$. tabescens by some authors) and A. tabescens should be treated as a single species. Four main phylogenetic lineages, referred to as the A. ostoyae, A. gallica, A. tabescens and A. mellea clusters, were identified on the phylogenetic trees. The unnamed biological
\end{abstract}


species grouped within the "A. gallica cluster" and were phylogenetically closely related. The results of this study contribute to our current understanding of the systematics of Armillaria from South East Asia where these fungi are relatively poorly known.

Keywords: Fungal diagnostics, Intergenic spacer region one (IGS-1), Root rot, Transcription elongation factor one alpha (TEF-1 $\alpha)$ gene

\section{Introduction}

Species of Armillaria (Fr.) Staude are well-known in China and other parts of the world where some are important pathogens mainly of woody plants (Shaw and Kile 1991; Baumgartner et al. 2011). Some Armillaria species are primary pathogens, causing the disease generally referred to as Armillaria root rot, which is considered amongst the most serious diseases of trees in boreal and temperate forests and various species damage high-value crops. Other species are important components of woody ecosystems by virtue of their saprophytic life strategy, where they contribute significantly to wood degradation (Gregory et al. 1991; Kile et al. 1991). Armillaria species also have an important role in the traditions of various Asian cultures as a source of nutrients or linked to traditional medicine (Hobbs 1986). For example, the mushroom fruiting structures of some edible species are utilized as a food source or used in the treatment of hypertension, neurasthenia and epilepsy (Hobbs 1986).

The taxonomy of Armillaria is largely based on the morphological and biological species concepts (Baumgartner et al. 2011). As additional species have been described, basidiocarp morphology has provided increasingly limited value and the biological species concept, reliant on reproductive isolation (Mayr 1942), has been increasingly useful (e.g., Morrison et al. 1985; Proffer et al. 1987; Dumas 1988; Coetzee et al. 2003b). This approach gained popularity in the late 1970's with the introduction of mating tests to differentiate Armillaria species (Korhonen 1978; Anderson and Ullrich 1979) and it remains a useful method in taxonomic studies. The morphological and biological species concepts have thus been applied to describe various taxa, including A. mellea subsp. nipponica, A. sinapina, A. gallica, A. ostoyae, A. cepistipes, A. ectypa, A. jezoensis, A. singula, A. nabsnona and various unnamed 
biological species from South East Asia (Sung et al. 1989, 1992; Mohammed et al. 1994; Cha and Igarashi 1995; Sung et al. 1995; Ota et al. 1998, 2009).

In a relatively recent study, Qin et al. (2007) expanded current knowledge regarding the Armillaria species diversity in China. Using mating studies, fourteen Chinese Biological Species (CBS A to D and F to O) of Armillaria were identified among isolates that were collected from 15 provinces of northern and southern China. Eight CBS (C, F, G, H, J, L, N and O) were unnamed, while the remainder included $A$. sinapina (CBS A), A. gallica (CBS B), A. solidipes (CBS D), formerly treated as A. ostoyae (Burdsall and Volk 2008) and pending nomenclatural conservation (Redhead et al. 2011), A. tabescens (CBS I), heterothallic A. mellea (CBS K), homothallic A. mellea (CBS G, suggested to represent A. mellea subsp. nipponica) and A. borealis (CBS M). Based on morphological characteristics, Qin et al. (2007) suggested that CBS F could be A. singula, a species that has been reported from Japan (Cha et al. 1994). However, mating tests were not performed to support this assertion.

Mating studies done by Qin et al. (2007) showed that CBS I is compatible with tester strains of A.tabescens from Europe. The taxonomy of A.tabescens from Asia, Europe and North America is, however, controversial mainly because sexual compatibility studies have provided inconclusive results. Preliminary results of Darmono et al. (1992), based on sexual compatibility tests between North American strains of $A$.tabescens and one strain identified as A. tabescens from Italy, suggested that $A$. tabescens from the two continents represent the same taxon. In contrast, Guillaumin et al. (1993) found that strains from Europe identified as A. tabescens are intersterile with North American strains of this species. Kile et al. (1994) subsequently proposed that A. tabescens from North America should be treated as a distinct species and referred to as A. monadelpha, a name that is considered illegitimate by Volk and Burdsall (1995). Ota et al. (1998) reported that Japanese isolates were interfertile with European isolates but intersterile with one North American isolate of this species. Although this would resolve some of these discrepancies, a phylogenetic study of these species has not been undertaken.

On the basis of their basidiocarp and culture morphology, the Chinese biological species were assigned to one of the species clusters introduced by Korhonen (1995). These clusters comprise species that share morphological characteristics and that are 
phylogenetically closely related. The clusters were referred to by Korhonen (1995) as the "A. ectypa cluster", “A. gallica cluster" (including A. altimontana, A. calvescens, A. cepistipes, A. gallica, A. nabsnona, A. sinapina, A. singula and A. jezoensis), “A. mellea cluster", "A. ostoyae cluster" (A. ostoyae, A. borealis and A. gemina) and "A. tabescens cluster" (A. tabescens and A. monadelpha). Based on their morphological characteristics, the unnamed biological species from China (C, F, H, J and L) were suggested to reside in the "A. gallica cluster", while CBS N and CBS O were not placed in any of the clusters (Qin et al. 2007). Despite the availability of techniques to resolve such questions, nothing is known regarding the phylogenetic relationships of the unnamed Chinese biological species with those of Armillaria spp. from other parts of the world.

Phylogenetic methods utilising DNA sequence data have been widely employed to elucidate the identity of field isolates of Armillaria (Coetzee et al. 2003a, b, 2005b; Keča et al. 2006; Sekizaki et al. 2008; Kikuchi and Yamaji 2010; Elías-Román et al. 2013) and to resolve the phylogenetic relationships of Armillaria species from various parts of the world (Maphosa et al. 2006; Coetzee et al. 2011). For phylogenetic inference, the internally transcribed spacer regions (ITS) and intergenic spacer region one (IGS-1) have been useful in studies focused on the relationships of taxa from Africa (Coetzee et al. 2005a), South America (Pildain et al. 2009), Australasia (Coetzee et al. 2001), North America (Anderson and Stasovski 1992), Europe (Chillali et al. 1998) and Asia (Terashima et al. 1998; Coetzee et al. 2000). In addition, sequences for part of the transcription elongation factor one alpha (TEF-1 $\alpha)$ gene has been used to determine the phylogenetic relationships of taxa from Japan (Hasegawa et al. 2010), Europe (Tsykun et al. 2013) and a global collection of isolates of Armillaria species (Maphosa et al. 2006). Despite the importance of Armillaria in China, there have not been studies to determine the phylogenetic relationships of Chinese biological species.

The aims of this study were to address some of the unresolved questions that emerged from the research of Qin et al. (2007). The identity of the unnamed CBS F was considered and a species recognition approach based on gene genealogical concordance was followed to assess the suggested differentiation of European and South East Asian A. tabescens from its North American counterpart. An additional aim was to determine 
the phylogenetic relationships between the Chinese biological species and Armillaria species from other regions of the world.

\section{Materials and methods}

\subsection{Fungal isolates}

Isolates included in this study that represent different Chinese Biological Species (Supplementary Table S1) were obtained from the culture collection of Dr. J. Zhao and were previously assigned to biological species in the study by Qin et al. (2007). Additional isolates from other parts of the world were also included to expand the geographical representation of Armillaria species in the Northern Hemisphere Armillaria phylogeny (Supplementary Table S2). Isolates were grown on malt yeast agar (MYA: $1.5 \% \mathrm{w} / \mathrm{v}$ malt extract, $0.2 \% \mathrm{w} / \mathrm{v}$ and yeast extract $1.5 \% \mathrm{w} / \mathrm{v}$ agar) medium. Isolates are maintained in the culture collection (CMW) of the Forestry and Agricultural Biotechnology Institute (FABI), University of Pretoria.

\subsection{DNA sequencing}

DNA was extracted from isolates representing each of the CBS and other Armillaria species following the methods outlined in Coetzee et al. (2005a). PCR reaction conditions and mixtures were the same as those described by Coetzee et al. (2003b) for the IGS-1 region, and Maphosa et al. (2006) for the TEF-1 $\alpha$ gene. The IGS-1 region was amplified for all isolates using primers P-1 (Hsiau 1996) and O-1 (Duchesne and Anderson 1990). Amplicons for the partial TEF-1 $\alpha$ gene were obtained using primer pair EF595F / EF1160R (Kauserud and Schumacher 2001). Amplicons were purified with a MSB ${ }^{\circledR}$ Spin PCRapace purification kit (Invitek) following the instructions of the manufacturer prior to DNA sequencing. DNA sequences were obtained in both directions for each PCR product with the same primers used for their amplification. Sequencing reactions were done using a BigDye Terminator v3.1 cycle sequencing kit (ABI) following the protocol outlined by the manufacturer. Sequences were determined 
on an ABI 3100 DNA automated sequencer. Base calling was visually inspected in CLC Main Workbench (CLC) and forward and reverse strands were assembled into contigs using the same software. The sequences obtained were used in DNA sequence similarity searches against those in GenBank using Blastn to ensure the identity of the isolates.

\subsection{Phylogenetic methods}

IGS-1 and TEF-1 $\alpha$ sequences were obtained from GenBank for Armillaria species from other parts of the world (Supplementary Table S2). Sequences selected from GenBank were from well characterised isolates used in previously published studies (see Supplementary Table S2 for references). These sequences together with those for the isolates included in this study formed the IGS-1 and TEF-1 $\alpha$ Northern Hemisphere Armillaria species matrices, respectively. All multiple sequence alignments (TreeBase Study number: S17215) were done using MAFFT (Katoh et al. 2013) and applying the default settings. Nucleic substitution models were determined with jModelTest (Posada 2008). Phylogenetic trees were generated based on maximum likelihood and Bayesian inference or maximum likelihood and parsimony. In each analysis, the IGS-1 and TEF$1 \alpha$ data were analysed separately. Armillaria mellea was used as the outgroup taxon in all analyses.

Maximum likelihood analyses were done using PHYML v. 3.0 (Guindon et al. 2010). The analyses incorporated substitution models that best fitted the individual data sets (Supplementary Table S3) and these were applied using a custom model setting in PHYML. The maximum likelihood trees that were obtained were rooted to A. mellea. Confidence levels for the nodes were obtained through a bootstrap analysis (1000 replicates) using the same settings employed to search tree-space for the fundamental maximum likelihood tree.

Bayesian inference of phylogenies was determined using MrBayes 3.2.1 (Huelsenbeck and Ronquist 2001). The likelihood and prior settings were based on the models for each dataset obtained from the analyses using jModelTest (Supplementary Table S3). For analyses of the combined data sets, a model, specific to each data partition was used. Posterior probability distributions were obtained by setting the Markov Chain Monte Carlo (MCMC) function to $4 \times 10^{6}$ generations for each analysis 
with a sampling frequency of every 100th tree. Posterior probability values were calculated after excluding (burnin) $25 \%$ of the trees generated during the MCMC analysis. ESS (Estimated Sample Size) values for the parameters were subsequently assessed in Tracer v. 1.5 (http://tree.bio.ed.ac.uk/software/tracer/) as a measure of convergence. The trees generated were viewed in FigTree v. 1.4.0 (http://tree.bio.ed.ac.uk/software/figtree/) to obtain tree topologies and the posterior probability values for their nodes.

Parsimony analyses were conducted using PAUP ver. 4 (Swofford 2002) and employed a heuristic tree search algorithm with 10 replicates of random addition of sequences and TBR branch swapping. Confidence levels at the nodes were determined using bootstrap analyses (1000 replicates) with the same settings but with the addition of sequences set to "closest". Missing, ambiguous and uninformative characters were excluded in all parsimony-based analyses.

\subsection{Assessing the conspecificity of $C B S F$ and A. singula}

IGS-1 sequences generated for isolates belonging to CBS F were compared with sequences of Armillaria in GenBank using Blastn searches. The available IGS-1 sequence (D89926) for $A$. singula in GenBank was downloaded and aligned with sequences of CBS F. Percentage similarity, converted from p-distances, was then determined in MEGA 6 (Tamura et al. 2013) and compared against those obtained from Blastn searches for other Armillaria species. In addition, the phylogenetic placement of CBS F and A. singula was assessed in a phylogenetic tree generated for the Northern Hemisphere Armillaria species.

\subsection{Phylogeny of isolates from Europe, North America and South East Asia identified as A. tabescens}

In addition to the $A$. tabescens sequences included in Northern Hemisphere Armillaria species matrices, other available IGS-1 and TEF-1 $\alpha$ DNA sequences for this species were downloaded from GenBank. These were aligned with sequences of $A$. tabescens and A. mellea generated in this study (Supplementary Table S1). Phylogenetic trees 
were obtained separately for the IGS- 1 and TEF- $1 \alpha$ data matrices based on parsimony and maximum likelihood. The grouping of isolates representing A. tabescens was also assessed in the context of a Northern Hemisphere Armillaria species phylogeny.

2.6. Phylogenetic relationships of Chinese Armillaria species with those from other parts of the world

Phylogenetic trees were constructed from the IGS-1 and TEF- $1 \alpha$ Northern Hemisphere Armillaria species matrices separately based on maximum likelihood and Bayesian analyses as described above.

\section{Results}

\subsection{Amplification of the IGS-1 and TEF-1 $\alpha$ regions}

The IGS-1 and EF- $1 \alpha$ regions consistently yielded a single band after PCR. The amplicon size for the IGS-1 region varied among the CBS, ranging from 600 bp to 900 bp. Amplification of the EF-1 $\alpha$ yielded an amplicon size of approximately $600 \mathrm{bp}$.

\subsection{Assessing the conspecificity of $C B S F$ and A. singula}

Isolates belonging to CBS F and considered by Qin et al. (2007) to represent A. singula had the highest IGS-1 sequence similarity to those of A. cepistipes, A. gallica and A. altimontana (99\% similarity) in GenBank. In contrast, sequence comparisons after aligning the IGS-1 sequence of $A$. singula from GenBank with those for the isolates representing CBS F revealed a 98\% sequence similarity.

Phylogenetic trees generated from the IGS-1 data matrix separated the isolates representing CBS F and the sequence of $A$. singula in well supported monophyletic groups (Fig. 1). Armillaria singula grouped closest to A. gallica from Japan ( $\mathrm{PP}=1$, bootstrap $=91 \%)$ within a monophyletic group that included A. jezoensis $(\mathrm{PP}=0.96$, bootstrap $=68 \%)($ Fig. 1). Together this group formed a monophyletic group with $A$. 


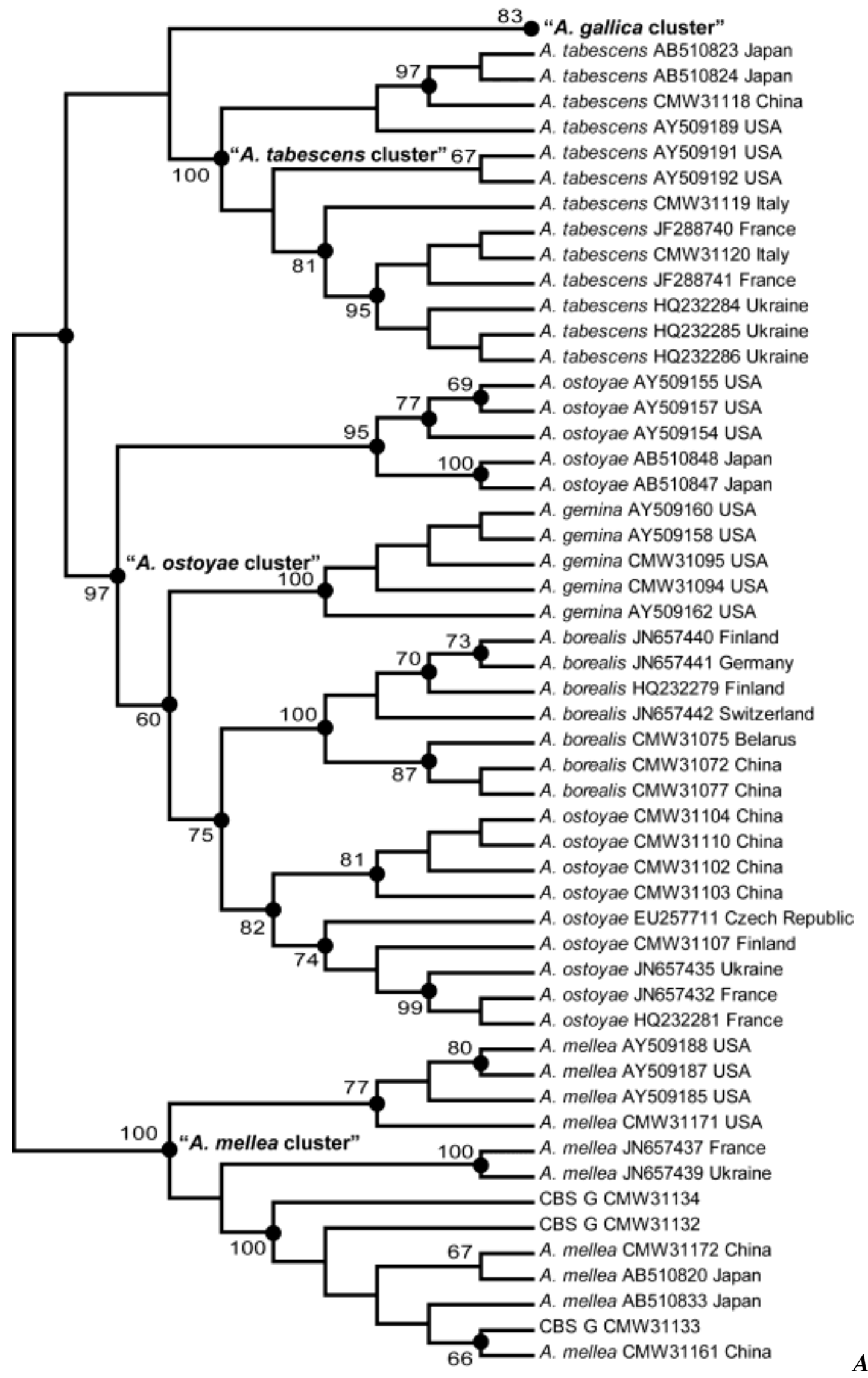




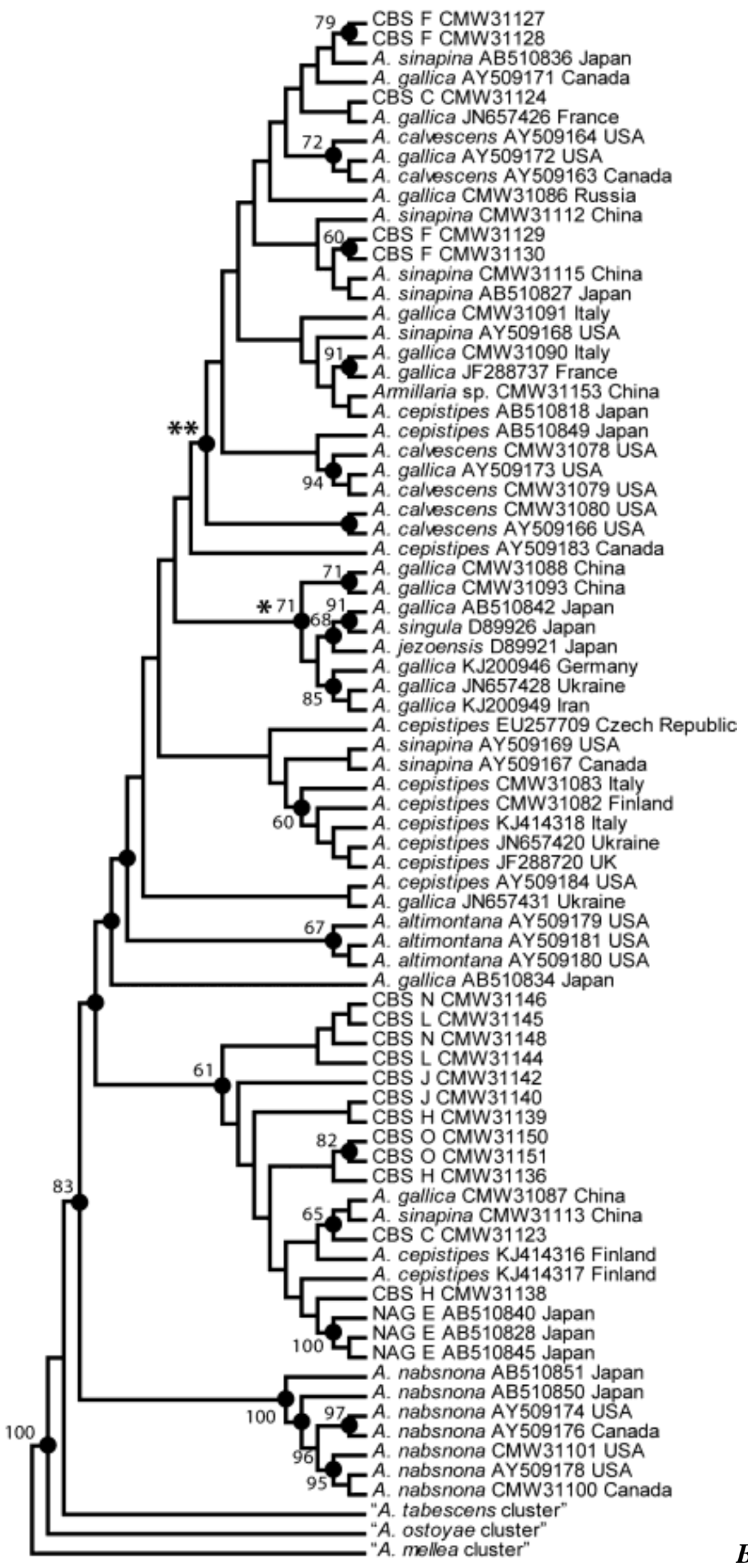


Fig. 1 - Phylogenetic tree generated from IGS-1 sequences based on maximum likelihood and converted to a cladogram for a collection of Northern Hemisphere Armillaria species. A: Phylogenetic relationships of species in the "A. mellea", "A. ostoyae" and "A. tabescens" clusters with isolates in the "A. gallica cluster" collapsed to a single terminal node. B: Phylogeny of species in the "A. gallica cluster" with isolates in the A. mellea, A. ostoyae and A. tabescens clusters collapsed to single terminal nodes. Bootstrap values $(\geq 60 \%)$ based on maximum likelihood are indicated at the nodes. Posterior probability values $(\geq 0.90)$ are indicated with circles at the nodes. The four main lineages are shown on the branches of the tree. (*) node shared by A. gallica, A. jezoensis and A. singula $(\mathrm{PP}=1$, bootstrap $=71 \%)$. $(* *)$ node shared by CBS F, CBS C (CMW31124) A. calvescens, A. cepistipes, A. gallica and A. sinapina $(\mathrm{PP}=1$, bootstrap $=58 \%)$.

gallica from Europe and China $(\mathrm{PP}=1$, bootstrap $=71 \%)$. Isolates belonging to CBS $\mathrm{F}$ resided in monophyletic group that constituted A. calvescens, A. cepistipes, A. gallica and A. sinapina $(\mathrm{PP}=1$, bootstrap $=58 \%)($ Fig. 1$)$.

\subsection{Phylogeny of isolates from Europe, North America and South East Asia identified as A. tabescens}

Phylogenetic trees generated for the Northern Hemisphere collection of Armillaria species placed all isolates of A. tabescens in a strongly supported monophyletic group (both IGS-1 and TEF-1 $\alpha$ : PP = 1, bootstrap = 100\%) (Figs. 1A, 2A). Phylogenetic trees generated for isolates from China and a larger collection of sequences obtained from GenBank for A. tabescens yielded incongruent topologies for the phylogenetic trees generated from IGS-1 and TEF-1 $\alpha$ sequences (Supplementary Figure S1). Trees obtained from IGS-1 sequence data placed the isolates from Japan and China in a clade that included sequences for A. tabescens from North America. Trees based on TEF-1 $\alpha$ sequences grouped the isolates from Asia with sequences of $A$. tabescens originating in Europe. In all phylogenetic trees, the Asian isolates formed a sub-clade with high bootstrap support (IGS-1: maximum likelihood 99\%, parsimony 100\%; TEF-1 $\alpha$ : $86 \%$ for both analyses). 


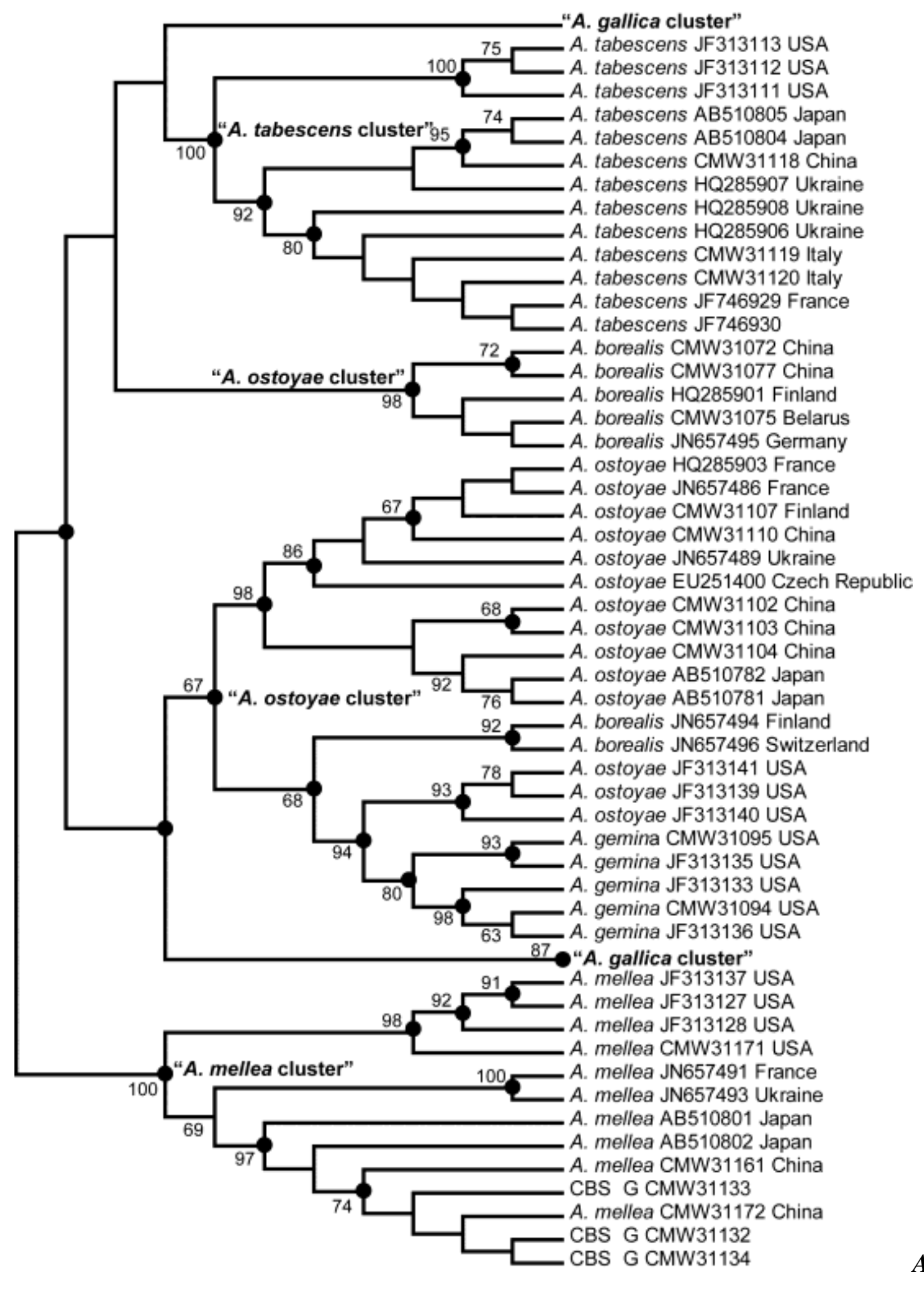




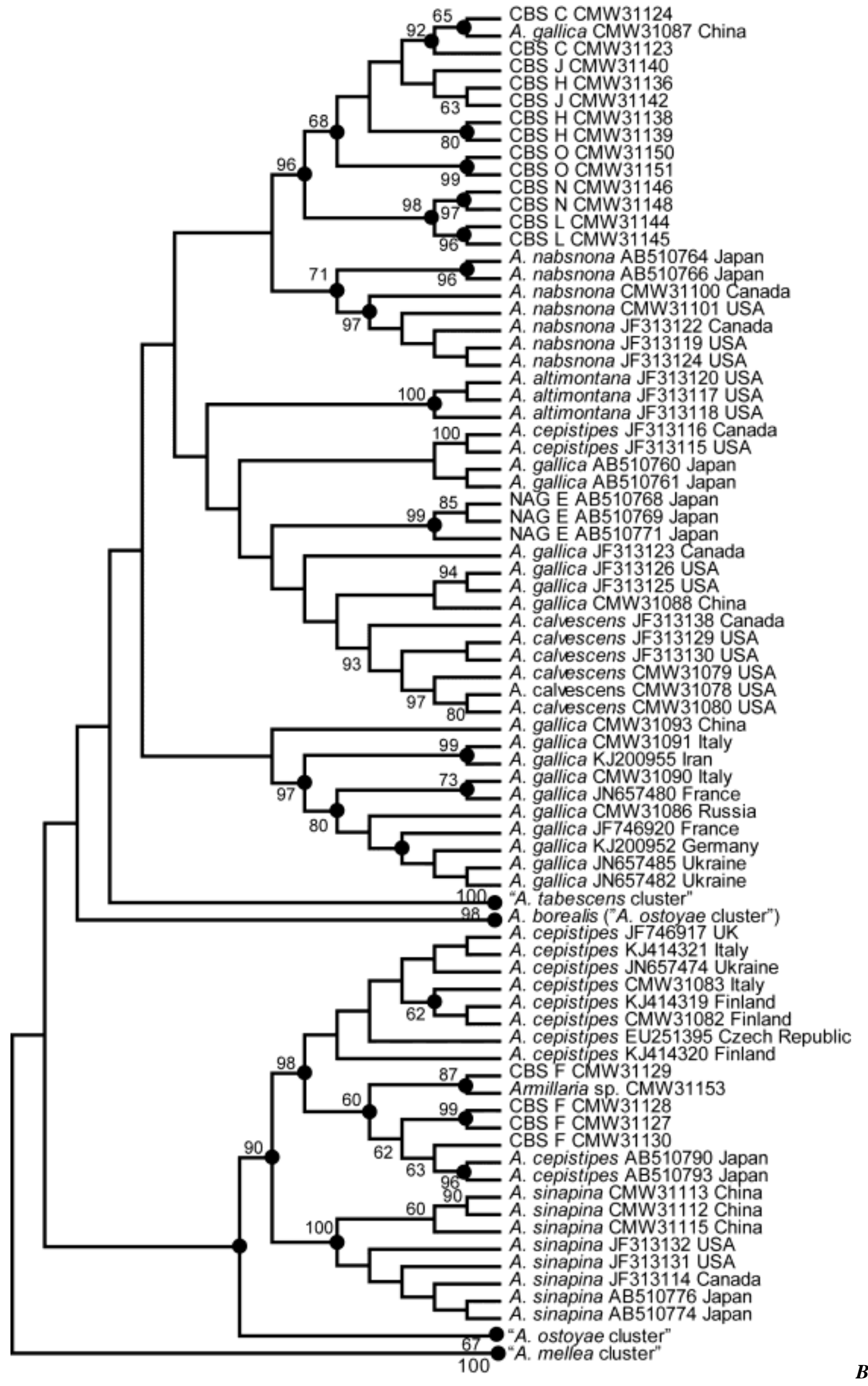


Fig. 2 - Phylogenetic tree, based on maximum likelihood analysis of TEF-1 $\alpha$ sequences and converted to a cladogram, showing the relationships isolates for a collection of Northern Hemisphere Armillaria species. A: Phylogenetic relationships of species in the "A. mellea”, "A. ostoyae” and "A. tabescens" clusters with isolates in the "A. gallica cluster" collapsed to a single terminal node. B: Phylogeny of species in the "A. gallica cluster" with isolates in the "A. mellea", "A. ostoyae" and "A. tabescens" clusters collapsed to single terminal nodes. Bootstrap values $(\geq 60 \%)$ based on maximum likelihood are indicated at the nodes. Posterior probability values $(\geq 0.90)$ are indicated with circles at the nodes.

\subsection{Phylogenetic relationships of Chinese Armillaria species with those from other} parts of the world

Phylogenetic trees generated from the different data matrices differed in their resolution and grouping of Armillaria species (Figs. 1,2). Phylogenetic trees generated from the IGS-1 sequence data generally yielded high bootstrap support at the nodes (Fig. 1). In contrast, trees generated from the TEF-1 $\alpha$ sequence data had low resolution at the deeper nodes (Fig. 2). In general, four groups emerged from the IGS-1 sequence matrix (Fig. 1). Following the Armillaria cluster names of Korhonen (1995), these groups are referred as the "A. mellea", "A. tabescens", "A. ostoye" and "A. gallica" clusters, respectively.

The "A. ostoyae cluster" included isolates belonging to A. borealis, A. ostoyae and A. gemina. Isolates representing A. gemina clustered in a well supported group in all trees generated from the IGS-1 (Fig. 1A) and TEF-1 $\alpha$ (Fig. 2A) sequence data. Isolates belonging to A. borealis were placed in a strongly supported group based on IGS-1 sequence data (Fig. 1A). However, isolates of this species from China, Belarus, Germany and Finland were placed distant to isolates belonging to the same species from Finland and Switzerland as well as A. gemina and A. ostoyae on the trees obtained from the TEF-1 $\alpha$ sequence matrix (Fig. 2A). Trees generated from the IGS-1 sequence matrix placed isolates of $A$. ostoyae from China and Europe in two distinct groups, and together they formed a sister group to A. borealis (Fig. 1A). Isolates of A. ostoyae from Japan and the USA grouped sister to A. gemina, A. borealis and the cluster that included isolates of this species from Europe and China (Fig. 1A). Trees generated from the TEF-1 $\alpha$ sequence matrix grouped isolates of A. ostoyae from China, Japan and Europe in a well supported group, while isolates from the USA formed a group with high support and were placed sister to A. gemina (Fig. 2A). 
The “A. gallica cluster" included A. calvescens, A. cepistipes, A. gallica, A. sinapina, A. nabsnona and the unnamed biological species CBS C, CBS F, CBS H, CBS J, CBS L, CBS N and CBS O (Figs. 1B, 2B). With the exception of some species, most of the isolates could not be separated into monophyletic groups representing their respective species assignments. In this cluster, isolates representing A. altimontana, A. nabsnona and NAG E were placed in their distinctive species groups with high statistical support on trees generated from the IGS-1 (Fig. 1B) and TEF-1 $\alpha$ (Fig. 2B) matrices, respectively. Isolates representing A. calvescens formed a strongly supported monophyletic group in phylogenetic trees obtained from the IGS-1 sequence matrix (Fig. 1B), but this was not the case for phylogenetic trees based on the TEF-1 $\alpha$ matrix (Fig. 2B). With the exception of CBS $\mathrm{J}$ and $\mathrm{H}$, all remaining isolates belonging to $\mathrm{CBS}$ grouped together forming their respective species groups based on TEF-1 $\alpha$ sequence data (Fig. 2B). Armillaria nabsnona formed a sister group with the remaining species having strong bootstrap support and PP = 1 based on the IGS-1 sequences (Fig. 1B). Isolates residing in CBS C (only isolate CMW31123), H, J, L, N, O grouped together with NAG E, A. cepestipes, A. gallica and A. sinapina on the trees generated from IGS1 sequences (Fig. 1B). The grouping of CBS C, H, J, L, N, O and A. gallica (CMW31087) was supported by the trees generated from TEF-1 $\alpha$ sequences (Fig. 2B). Within this group, CBS L and CBS N were placed sister to each other with high bootstrap support and posterior probability (Fig. 2B). Chinese biological species $\mathrm{F}$ together with an isolate belonging to CBS C (CMW31124) clustered with isolates representing A. calvescens, A. cepistipes, A. gallica and A. sinapina based on the IGS-1 sequence matrix (Fig. 1B). CBS F clustered with isolates belonging to A. cepistipes (PP $=0.98$, bootstrap $=98 \%$ ) and together, these species were grouped sister to A. sinapina based on the TEF- $1 \alpha$ sequence data (Fig. 2B).

\section{Discussion}

Although Armillaria spp. are common in China, very little work has been done to identify these fungi. This is the first study to apply DNA sequence analyses to consider the identity of a relatively large collection of isolates from the country, and to assess the phylogenetic relationships among these isolates and those known from other parts of the 
world. The specific aims of this study were to determine the identity of the unnamed CBS F, to consider the suggestion that $A$. tabescens from North America should be treated as a species different from its European and Asian counterparts and to determine the phylogenetic relationships of Armillaria species from China.

\subsection{Identity of $C B S F$}

Qin et al. (2007) suggested that CBS F and A. singula are conspecific on the basis of their basidiocarp morphology. Armillaria singula was described from Hokkaido (Cha et al. 1994) and it has not been found elsewhere (Ota et al. 1998). There is only one IGS-1 sequence for this species (Terashima et al.1998) and no living cultures are known to exist (Ota et al. 2012).

Results of Blastn searches and phylogenetic analyses of the IGS-1 region revealed that CBS F possibly represents an undescribed Armillaria sp. other than A. singula but closely related to A. calvescens, A. cepistipes, A. gallica and A. sinapina. IGS-1 DNA sequences of isolates belonging to CBS F were most similar to those of $A$. cepistipes, A. gallica and A. altimontana on GenBank. Phylogenetic trees generated from IGS-1 sequences grouped CBS F distant from $A$. singula and together with $A$. calvescens, A. cepistipes, A. gallica and A. sinapina with high bootstrap support and high posterior probability. Phylogenetic trees based on TEF-1 $\alpha$ sequences grouped representatives of CBS F and A. cepistipes together with high bootstrap support. Isolates of CBS F were, however, sexually incompatible with those of A. cepistipes, A. gallica and A. sinapina in the study of Qin et al. (2007). Although the results of the current study are not conclusive, given the fact that IGS-sequences could not resolve isolates identified as A. gallica, A. cepistipes and A. sinapina into their respective species groups on the phylogenetic trees, it suggests that CBS F represents a novel taxon. Future research should focus on obtaining isolates belonging to $A$. singula so that mating tests and phylogenetic studies can be conducted in order to reach a definitive identification. 


\subsection{Are Armillaria tabescens isolates from Asia, Europe and North America}

conspecific?

Results of this study suggest that A. tabescens from Asia, Europe and North America should be treated as a single taxon. Phylogenetic trees grouped isolates of A.tabescens from various parts of the world in a strongly supported monophyletic group on trees generated in this study for a large collection of isolates belonging to different Armillaria species. Phylogenetic trees placed isolates of A. tabescens from China in a monophyletic group with those from Japan. Trees generated from IGS-1 and TEF-1 $\alpha$ sequence data were, however, incongruent in the placement of this group relative to isolates of A. tabescens from Europe and North America. Although only two loci were used in this study, application of genealogical concordance phylogenetic recognition (Taylor et al. 2000) indicates that these isolates are conspecific. Results of the present study thus support the view that A. tabescens from Asia, Europe and North America should be treated as a single taxon. However, further studies including a larger collection and a broader distribution of isolates from the Northern Hemisphere should be undertaken to confirm these results.

\subsection{Phylogeny of Armillaria species from China}

Phylogenetic trees generated from the IGS-1 region and partial TEF-1 $\alpha$ gene for the collection of isolates from China used in this study generally resolved four main phylogenetic groups. These are referred to as the "A. ostoyae", "A. gallica", "A. tabescens" and "A. mellea" clusters and they are more or less consistent with those defined by Korhonen (1995). The "A. ostoyae cluster" included A. ostoyae (CBS D), A. borealis (CBS M) and A. gemina. The "A. gallica cluster" formed the largest group and included A. gallica (CBS B), A. sinapina (CBS A), CBS C, CBS F, CBS H, CBS J, CBS $\mathrm{K}, \mathrm{CBS} \mathrm{L}, \mathrm{CBS} \mathrm{N}$ and CBS $\mathrm{O}$ as well as A. altimontana, A. calvescens, A. cepistipes, $A$. nabsnona and NAG E. The "A. mellea cluster" was represented by isolates belonging to A. mellea s.s. (CBS K) and CBS G.

The unnamed Armillaria Chinese biological species H, J, L, N and $\mathrm{O}$ were suggested to be closely related to members of the A. gallica cluster based on the 
characteristics of their basidiocarps (Qin et al. 2007). This view was supported in the present study where isolates representing these biological species formed a monophyletic group that included A. gallica and its closest relatives in the phylogenetic trees generated from IGS-1 and TEF-1 $\alpha$ sequences. Trees obtained from the IGS-1 sequences also showed a close relationship between these biological species and NAG E from Japan, although this only had low bootstrap support. The phylogenetic relationships among the Chinese biological species could not be resolved based on IGS1 sequences due to poor phylogenetic resolution. In contrast, TEF-1 $\alpha$ sequences provided better resolution for these biological species. Phylogenetic trees generated from the latter sequences revealed a close relationship between CBS L and CBS N and that they have a sister relationship with CBS C, CBS H, CBS J and CBS O.

Determining the phylogeny of Armillaria species from China was complicated by gene trees that differed in their topologies and phylogenetic resolution. Incongruence in the placement of isolates belonging to CBS C, A. borealis, A. cepistipes, A. gallica, A. sinapina and A. ostoyae, was observed on trees generated respectively from IGS-1 and TEF- $1 \alpha$ sequences in this study. Phylogenetic trees obtained from the IGS-1 region grouped the isolates belonging to CBS C in two different clusters, while they grouped together on trees generated from TEF- $1 \alpha$ sequences. Similarly, isolates identified as $A$. sinapina were placed at different positions on trees generated from the IGS-1 region, while they formed a monophyletic group on the tree obtained from TEF-1 $\alpha$ sequences. Isolates belonging to A. borealis formed a monophyletic group in the tree generated from the IGS-1 matrix, while they were separated into distantly related groups on the TEF-1 $\alpha$ phylogenetic trees. Isolates belonging to A. ostoyae were grouped in two monophyletic groups on trees obtained from the IGS-1 and TEF-1 $\alpha$ matrices. Isolates of A. gallica and A. cepistipes were scattered within the "A. gallica cluster" in trees generated for both loci, however, isolates of A. gallica from Europe and Iran formed a monophyletic group on the tree obtained from TEF-1 $\alpha$ sequences. The discordance between the gene trees could be ascribed to incomplete lineage sorting as result of recent divergence (Maddison 1997). A larger sample size and additional gene regions would be required to resolve this question, but the results are congruent with those of earlier studies (Maphosa et al. 2006; Mulholland et al. 2012; Ross-Davis et al. 2012; 
Tsykun et al. 2013) suggesting that the TEF-1 $\alpha$ gene will be well- suited for species identification based on sequence comparisons.

The results of this study contribute to our current understanding of the systematics of Armillaria, and more specifically Armillaria species from South East Asia. With the exception of a few phylogenetic studies that have focused on the species occurring in Japan (Terashima et al. 1998; Hasegawa et al. 2010; Ota et al. 2012), nothing was previously known regarding the phylogeny of Chinese Armillaria species prior to this study. This study also expanded the current IGS-1 and TEF-1 $\alpha$ DNA sequence database for Armillaria species and the data can now be employed in future research to identify field isolates from China using sequence comparisons. Clearly, many questions remain regarding the identity of the genus Armillaria from China. In this regard, the most important challenge ahead will be to collect isolates linked to sporocarps and to study these using all available taxonomic tools for Armillaria. There are clearly numerous novel species in China and these deserve to be named and studied.

\section{Disclosure}

The authors declare no conflicts of interest. All the experiments undertaken in this study comply with the current laws of the country where they were performed.

\section{Acknowledgments}

We thank the members of the Tree Protection Co-operative Programme (TPCP), the National Research Foundation (NRF), the THRIP initiative of the Department of Trade and Industry and the DST/NRF Centre of Excellence in Tree Health Biotechnology (CTHB) South Africa for financial support. We are sincerely grateful to Dr K.

Korhonen for providing us with cultures of Armillaria, without which this research would not have been possible. 


\section{References}

Anderson JB, Stasovski E, 1992. Molecular phylogeny of Northern Hemisphere species of Armillaria. Mycologia 84: 505-516.

Anderson JB, Ullrich RC, 1979. Biological species of Armillaria mellea in North America. Mycologia 71: 402-414.

Baumgartner K, Coetzee MPA, Hoffmeister D, 2011. Secrets of the subterranean pathosystem of Armillaria. Molecular Plant Pathology 12: 515-534; doi: 10.1111/j.1364-3703.2010.00693.x.

Burdsall HH, Volk TJ, 2008. Armillaria solidipes, an older name for the fungus called Armillaria ostoyae. North American Fungi 3: 261-267.

Cha JY, Igarashi T, 1995. Armillaria species associated with Gastrodia elata in Japan. European Journal of Forest Pathology 25: 319-326.

Cha JY, Sung JM, Igarashi T, 1994. Biological species and morphological characteristics of Armillaria mellea complex in Hokkaido: A. sinapina and two new species, A. jezoensis and A. singula. Mycoscience 35: 39-47.

Chillali M, Wipf D, Guillaumin J-J, Mohammed C, Botton B, 1998. Delineation of the European Armillaria species based on the sequences of the internal transcribed spacer (ITS) of ribosomal DNA. New Phytologist 138: 553-561.

Coetzee MPA, Bloomer P, Wingfield MJ, Wingfield BD, 2011. Paleogene radiation of a plant pathogenic mushroom. Plos One 6: e28545; doi:

10.1371/journal.pone.0028545.

Coetzee MPA, Wingfield BD, Bloomer P, Ridley GS, Kile GA, Wingfield MJ, 2001. Phylogenetic relationships of Australian and New Zealand Armillaria species. Mycologia 93: 887-896.

Coetzee MPA, Wingfield BD, Bloomer P, Ridley GS, Wingfield MJ, 2003a. Molecular identification and phylogeny of Armillaria isolates from South America and Indo-Malaysia. Mycologia 95: 285-293.

Coetzee MPA, Wingfield BD, Bloomer P, Wingfield MJ, 2005a. Phylogenetic analyses of DNA sequences reveal species partitions amongst isolates of Armillaria from Africa. Mycological Research 109: 1223-1234. 
Coetzee MPA, Wingfield BD, Harrington TC, Dalevi D, Coutinho TA, Wingfield MJ, 2000. Geographical diversity of Armillaria mellea s. s. based on phylogenetic analysis. Mycologia 92 : 105-113.

Coetzee MPA, Wingfield BD, Kirisits T, Chhetri DB, Bloomer P, Wingfield MJ, 2005b. Identification of Armillaria isolates from Bhutan based on DNA sequence comparisons. Plant Pathology 54 : 36-45.

Coetzee MPA, Wingfield BD, Roux J, Crous PW, Denman S, Wingfield MJ, 2003b. Discovery of two northern hemisphere Armillaria species on Proteaceae in South Africa. Plant Pathology 52: 604-612.

Darmono TW, Burdsall HH, Volk TJ, 1992. Interfertility among isolates of Armillaria tabescens in North America. Sydowia 42 : 105-116.

Duchesne LC, Anderson JB, 1990. Location and direction of transcription of the 5S rRNA gene in Armillaria. Mycological Research 94: 266-269.

Dumas MT, 1988. Biological species of Armillaria in the mixedwood forest of northern Ontario Canada. Canadian Journal of Forest Research 18: 872-874.

Elías-Román RD, Guzmán-Plazola RA, Klopfenstein NB, Alvarado-Rosales D, Calderón-Zavala G, Mora-Aguilera JA, Kim MS, García-Espinosa R, 2013. Incidence and phylogenetic analyses of Armillaria spp. associated with root disease in peach orchards in the State of Mexico, Mexico. Forest Pathology 43: 390-401; doi: 10.1093/sysbio/syq010.

Gregory SC, Rishbeth J, Shaw CG, 1991. Pathogenicity and virulence. In: Shaw CG, Kile GA (eds), Armillaria root disease, Agriculture Handbook No. 691. Forest Service United States, Department of Agriculture, Washington D.C., pp 76-87. Guillaumin JJ, Mohammed C, Anselmi N, Courtecuisse R, Gregory SC, Holdenrieder O, Intini M, Lung B, Marxmuller H, Morrison D, Rishbeth J, Termorshuizen AJ, Tirro A, Van DB, 1993. Geographical distribution and ecology of the Armillaria species in western Europe. European Journal of Forest Pathology 23: 321-341.

Guindon S, Dufayard J-F, Lefort V, Anisimova M, Hordijk W, Gascuel O, 2010. New algorithms and methods to estimate maximum-likelihood phylogenies: Assessing the performance of PhyML 3.0. Systematic Biology 59: 307-321; doi: 10.1093/sysbio/syq010. 
Hasegawa E, Ota Y, Hattori T, Kikuchi T, 2010. Sequence-based identification of Japanese Armillaria species using the elongation factor-1 alpha gene. Mycologia 101: 898-910.

Hobbs C, 1986. Medicinal mushrooms: an exploration of tradition, healing, and culture. Botanica Press, Summertown, Tennessee.

Hsiau PT-W, 1996. The taxonomy and phylogeny of the mycangial fungi from Dendroctonus brevicomis and D. frontalis (Coleoptera: Scolytidae). $\mathrm{PhD}$ thesis, Iowa State University, Ames, Iowa.

Huelsenbeck JP, Ronquist F, 2001. MRBAYES: Bayesian inference of phylogenetic trees. Bioinformatics 17: 754-755; doi: 10.1093/bioinformatics/17.8.754.

Katoh K, Standley DM, 2013. MAFFT Multiple Sequence Alignment Software Version 7: Improvements in performance and usability. Molecular Biology and Evolution 30: 772-780; doi:10.1093/molbev/mst010.

Kauserud H, Schumacher T, 2001. Outcrossing or inbreeding: DNA markers provide evidence for type of reproductive mode in Phellinus nigrolimitatus (Basidiomycota). Mycological Research 105: 676-683.

Keča N, Bodles WJA, Woodward S, Karadzic D, Bojovic S, 2006. Molecular-based identification and phylogeny of Armillaria species from Serbia and Montenegro. Forest Pathology 36: 41-57; doi: 10.1111/j.1439-0329.2006.00434.x.

Kikuchi G, Yamaji H, 2010. Identification of Armillaria species associated with Polyporus umbellatus using ITS sequences of nuclear ribosomal DNA. Mycoscience 51: 366-372; doi: 10.1007/s10267-010-0053-8.

Kile GA, Guillaumin J-J, Mohammed C, Watling R, 1994. Biogeography and pathology of Armillaria. In: Johansson M, Stenlid J (eds), Proceedings of the eight international confrence on Root and Butt Rots, Sweden. Swedish University of Agricultural Sciences, S-750 07, Upsala, Sweden, pp 411-436.

Kile GA, McDonald GI, Byler JW, 1991. Ecology and disease in natural forests. In: Shaw CG, Kile GA (eds), Armillaria root disease, Agriculture Handboook No. 691. Forest Service United States Department of Agriculture, Washington D.C., pp 102-121.

Korhonen K, 1978. Interfertility and clonal size in the Armillariella mellea complex. Karstenia 18: 31-42. 
Korhonen K, 1995. Armillaria since Elias Fries. Acta Universitatis Upsaliensis Symbolae Botanicae Upsalienses 30: 153-161.

Maddison WP, 1997. Gene trees in species trees. Systematic Biology 46: 523-536.

Maphosa L, Wingfield BD, Coetzee MPA, Mwenje E, Wingfield MJ, 2006.

Phylogenetic relationships among Armillaria species inferred from partial elongation factor 1-alpha DNA sequence data. Australasian Plant Pathology 35: 513-520; doi: 10.1071/AP06056.

Mayr E, 1942. Systematics and the origin of species. Columbia University Press, New York.

Mohammed C, Guillaumin J-J, Berthelay S, 1994. Armillaria species identified in China and Japan. Mycological Research 98: 607-613.

Morrison DJ, Chu D, Johnson ALS, 1985. Species of Armillaria in British Columbia. Canadian Journal of Plant Pathology 7: 242-246.

Mulholland V, MacAskill GA, Laue BE, Steele H, Kenyon D, Green S, 2012.

Development and verification of a diagnostic assay based on EF-1 $\alpha$ for the identification of Armillaria species in Northern Europe. Forest Pathology 42: 229-238; doi: 10.1111/J.1439-0329.2011.00747.X.

Ota Y, Kim M-S, Neda H, Klopfenstein NB, Hasegawa E, 2012. The phylogenetic position of an Armillaria species from Amami-Oshima, a subtropical island of Japan, based on elongation factor and ITS sequences. Mycoscience 52: 53-58; doi: 10.1007/s10267-010-0066-3.

Ota Y, Matsushita N, Nagasawa E, Terashita T, Fukuda K, Suzuki K, 1998. Biological species of Armillaria in Japan. Plant Disease 82: 537-543.

Ota Y, Sotome K, Hasegawa E, 2009. Seven Armillaria species identified from Hokkaido Island, northern Japan. Mycoscience 50: 442-447.

Pildain MB, Coetzee MPA, Rajchenberg M, Petersen R, Wingfield MJ, Wingfield BD, 2009. Molecular phylogeny of Armillaria from the Patagonian Andes. Mycological Progress 8: 181-194; doi: 10.1007/s11557-009-0590-8.

Posada D, 2008. jModelTest: Phylogenetic model averaging. Molecular Biology and Evolution 25: 1253-1256; doi: 10.1093/molbev/msn083.

Proffer TJ, Jones AL, Ehret GR, 1987. Biological species of Armillaria isolated from sour cherry orchards in Michigan USA. Phytopathology 77: 941-943. 
Qin GF, Zhao J, Korhonen K, 2007. A study on intersterility groups of Armillaria in China. Mycologia 99: 430-441.

Redhead SA, Bérubé J, Cleary MR, Holdenrieder O, Hunt RS, Korhonen K, Marxmüller H, Morrison DJ, 2011. Proposal to conserve Armillariella ostoyae (Armillaria ostoyae) against Agaricus obscurus, Agaricus occultans, and Armillaria solidipes (Basidiomycota). Taxon 60 : 1770-1771.

Ross-Davis AL, Hanna JW, Klopfenstein NB, Kim M-S, 2012. Advances toward DNAbased identification and phylogeny of North American Armillaria species using elongation factor-1 alpha gene. Mycoscience 53: 161-165; doi:http://dx.doi.org/10.1007/S10267-011-0148-X.

Sekizaki H, Kuninaga S, Yamamoto M, Asazu SN, Sawa S, Kojoma M, Yokosawa R, Yoshida N, 2008. Identification of Armillaria nabsnona in Gastrodia tubers. Biological and Pharmaceutical Bulletin 31: 1410-1414; doi: JST.JSTAGE/bpb/31.1410.

Shaw CG, Kile GA, 1991. Armillaria root disease. Agriculture Handbook No. 691. Forest Service, United States Department of Agriculture, Washington, D.C., USA.

Sung JM, Cha JY, Harrington TC, 1992. Cultural characteristics and basidiome morphology of Armillaria gallica and A. ostoyae from Korea. Phytopathology 82: 1152 .

Sung JM, Cha JY, Kim YS, 1989. Identification and culture of Armillaria mellea complex associated with root rot disease of South Korean Pine. Korean Journal of Plant Pathology 5: 317-327.

Sung JM, Jung BS, Yang KJ, Lee HK, Harrington TC, 1995. Production of Gastrodia elata tuber using Armillaria spp. Korean Journal of Mycology 23: 61-70.

Swofford DL, 2002. PAUP*: Phylogenetic Analysis Using Parsimony (*and Other Methods). Vers. 4. Sinauer Associates, Sunderland, Massachusetts.

Tamura K, Stecher G, Peterson D, Filipski A, Kumar S, 2013. MEGA6: Molecular Evolutionary Genetics Analysis Version 6.0. Molecular Biology and Evolution 30: 2725-2729; doi: 10.1093/molbev/mst197. 
Taylor JW, Jacobson DJ, Kroken S, Kasuga T, Geiser DM, Hibbett DS, Fisher MC, 2000. Phylogenetic species recognition and species concepts in fungi. Fungal Genetics and Biology 31: 21-32; doi: 10.1006/fgbi.2000.1228.

Terashima K, Cha JY, Yajima T, Igarashi T, Miura K, 1998. Phylogenetic analysis of Japanese Armillaria based on the intergenic spacer (IGS) sequences of their ribosomal DNA. European Journal of Forest Pathology 28: 11-19.

Tsykun T, Rigling D, Prospero S, 2013. A new multilocus approach for a reliable DNAbased identification of Armillaria species. Mycologia 105: 1059-1076; doi: $10.3852 / 12-209$.

Volk TJ, Burdsall HH, 1995. A nomenclatural study of Armillaria and Armillariella species (Basidiomycotina, Tricholomataceae). Synopsis Fungorum 8. Fungiflora, Førde, Norway. 


\section{Supplementary data}
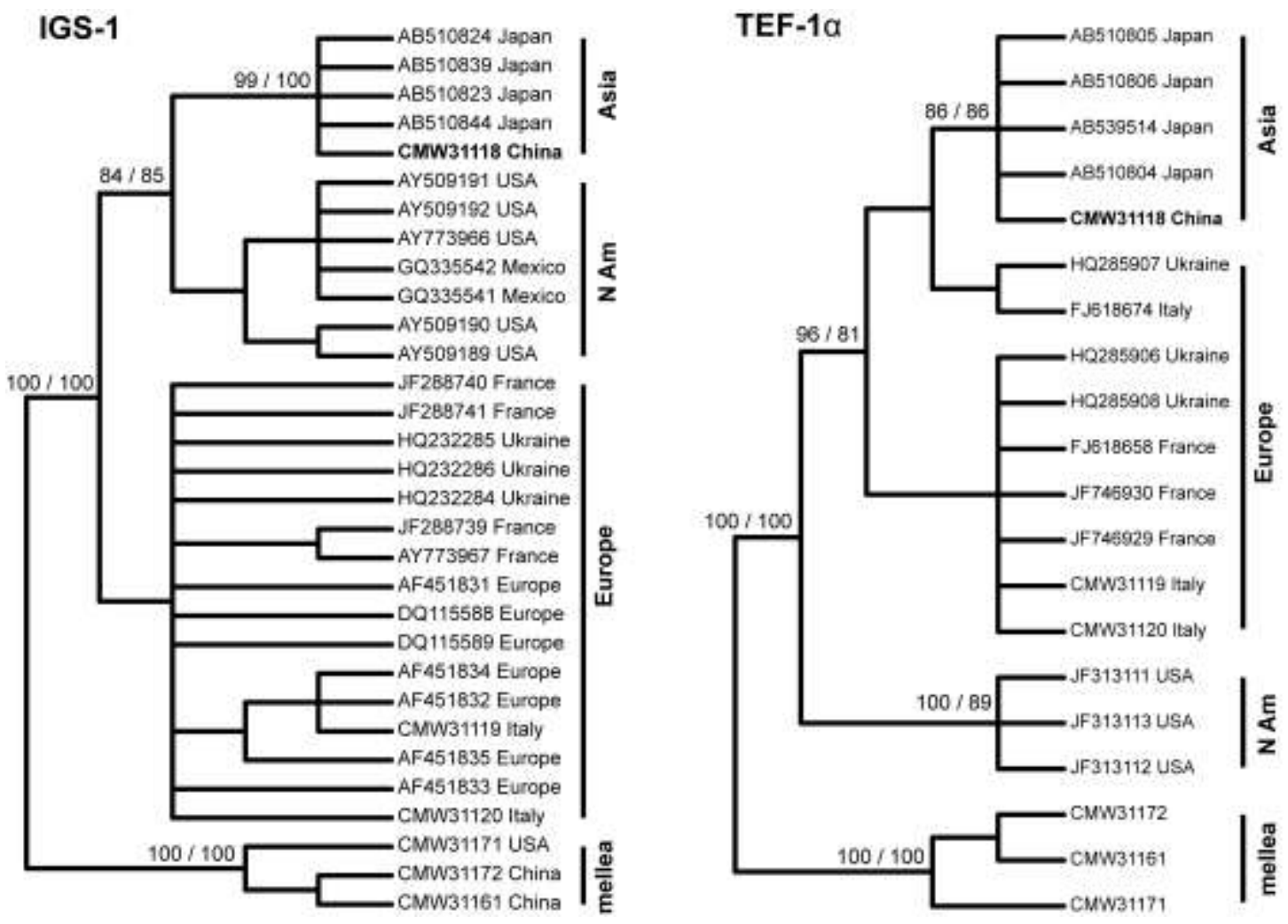

Supplementary Fig. S1 - Cladograms showing the relationship of isolates belonging to A. tabescens that originated from China, Japan, Europe and North America. Parsimony analysis yielded 26 most parsimonious trees for the IGS-1 matrix with tree lengths (TL) of 164 steps, consistency index (CI) $=0.96$ and retention index $(\mathrm{RI})=0.98$. The TEF- $1 \alpha$ matrix yielded four most parsimonious trees with $\mathrm{TL}=69$ steps, $\mathrm{CI}=0.96$ and $\mathrm{RI}=0.98$. Bootstrap values obtained from parsimony are shown at the nodes followed by those determined through maximum likelihood. Armillaria mellea was used as the outgroup taxon to root the trees. 
Supplementary Table S1 - Isolates from China used to determine the phylogenetic species among biological species of Armillaria from China.

\begin{tabular}{|c|c|c|c|c|c|}
\hline \multirow[t]{2}{*}{ Species } & \multirow{2}{*}{$\begin{array}{l}\text { CMW }^{\mathrm{a}} \text { culture } \\
\text { no. }\end{array}$} & \multicolumn{2}{|c|}{ Alternative no. } & \multicolumn{2}{|c|}{ GenBank accession no. } \\
\hline & & $\mathrm{KK}^{\mathrm{a}}$ & $\operatorname{Qin}^{\mathrm{a}}$ & IGS-1 & TEF- $1 \alpha$ \\
\hline \multirow[t]{2}{*}{ Armillaria borealis } & CMW31072 & $3348 / 5$ & 01015 & KM205304 & KM205251 \\
\hline & CMW31077 & $3354 / 1$ & 01013 & KM205306 & KM205253 \\
\hline \multirow[t]{3}{*}{ A. gallica } & CMW31087 & $3399 / 1$ & 96027 & KM205313 & KM205260 \\
\hline & CMW31088 & $3374 / 1$ & 02147 & KM205314 & KM205261 \\
\hline & CMW31093 & $3395 / 1$ & 96011 & KM205317 & KM205264 \\
\hline \multirow[t]{2}{*}{ A. mellea } & CMW31161 & $3336 / 5$ & 00109 & KM205320 & KM205267 \\
\hline & CMW31172 & 3329 & 00017 & KM205322 & KM205269 \\
\hline \multirow[t]{4}{*}{ A. ostoyae } & CMW31102 & $3412 / 1$ & 97058-B & KM205325 & KM205272 \\
\hline & CMW31103 & $3403 / 1$ & 96043 & KM205326 & KM205273 \\
\hline & CMW31104 & $3404 / 1$ & 96044 & KM205327 & KM205274 \\
\hline & CMW31110 & $3401 / 1$ & 96035 & KM205329 & KM205276 \\
\hline \multirow[t]{3}{*}{ A. sinapina } & CMW31112 & $3393 / 1$ & 93012 & KM205330 & KM205277 \\
\hline & CMW31113 & $3397 / 1$ & 96015 & KM205331 & KM205278 \\
\hline & CMW31115 & $3425 / 1$ & 99104 & KM205332 & KM205279 \\
\hline A. tabescens & CMW31118 & $3480 / 16$ & 99022 & KM205333 & KM205280 \\
\hline Armillaria sp. & CMW31153 & 3344 & 01009 & KM205336 & KM205283 \\
\hline \multirow[t]{2}{*}{$\mathrm{CBS}^{\mathrm{b}} \mathrm{C}$} & CMW31123 & $3428 / 8$ & 99110 & KM205337 & KM205284 \\
\hline & CMW31124 & $3409 / 2$ & 97047 & KM205338 & KM205285 \\
\hline \multirow[t]{4}{*}{ CBS F } & CMW31127 & $3355 / 1$ & 01107 & KM205339 & KM205286 \\
\hline & CMW31128 & $3424 / 1$ & 99102 & KM205340 & KM205287 \\
\hline & CMW31129 & $3405 / 1$ & 96060 & KM205341 & KM205288 \\
\hline & CMW31130 & $3426 / 1$ & 99107 & KM205342 & KM205289 \\
\hline \multirow[t]{3}{*}{ CBS G } & CMW31132 & $3345 / 1$ & 01010 & KM205343 & KM205290 \\
\hline & CMW31133 & $3422 / 1$ & 99044 & KM205344 & KM205291 \\
\hline & CMW31134 & $3356 / 1$ & 02001 & KM205345 & KM205292 \\
\hline \multirow[t]{3}{*}{ CBS H } & CMW31136 & $3419 / 1$ & 99012 & KM205346 & KM205293 \\
\hline & CMW31138 & $3320 / 6$ & 00006 & KM205347 & KM205294 \\
\hline & CMW31139 & $3328 / 1$ & 00015 & KM205348 & KM205295 \\
\hline
\end{tabular}


Supplementary Table S1 (continued)

\begin{tabular}{llllll}
\hline Species & CMW & Alternative no. & & GenBank accession no. \\
& & & & \\
& & KK $^{\mathrm{a}}$ & Qin $^{\mathrm{a}}$ & IGS-1 & TEF-1 $\alpha$ \\
& & & & \\
\hline CBS J & CMW31140 & $3154 / 1$ & & KM205349 & KM205296 \\
& CMW31142 & $3333 / 1$ & 00101 & KM205350 & KM205297 \\
CBS L & CMW31144 & $3342 / 1$ & 00125 & KM205351 & KM205298 \\
& CMW31145 & $3343 / 1$ & 00126 & KM205352 & KM205299 \\
CBS N & CMW31146 & $3365 / 3$ & 02068 & KM205353 & KM205300 \\
& CMW31148 & $3363 / 3$ & 02066 & KM205354 & KM205301 \\
CBS O & CMW31150 & $3369 / 2$ & 02072 & KM205355 & KM205302 \\
& CMW31151 & $3369 / 13$ & 02072 & KM205356 & KM205303
\end{tabular}

${ }^{\mathrm{a}}$ Culture collection abbreviations: Culture M. Wingfield (CMW), K. Korhonen (KK) and G.-F. Qin (Qin).

${ }^{\mathrm{b}}$ Chinese Biological Species 


\begin{tabular}{|c|c|c|c|c|c|}
\hline Species & Isolate & Country & IGS & TEF-1 $\alpha$ & Reference $^{a}$ \\
\hline \multirow[t]{3}{*}{ Armillaria altimontana } & 837 & Idaho, USA & AY509179 & JF313120 & $\begin{array}{l}\text { Kim et al. (2006), Ross- } \\
\text { Davis et al. (2012) }\end{array}$ \\
\hline & D82 & Idaho, USA & AY509180 & JF313118 & $\begin{array}{l}\text { Kim et al. (2006), Ross- } \\
\text { Davis et al. (2012) }\end{array}$ \\
\hline & POR100 & Idaho, USA & AY509181 & JF313117 & $\begin{array}{l}\text { Kim et al. (2006), Ross- } \\
\text { Davis et al. (2012) }\end{array}$ \\
\hline \multirow[t]{5}{*}{ A. borealis } & A1 & Finland & JN657440 & JN657494 & Tsykun et al. (2013) \\
\hline & A5 & Germany & JN657441 & JN657495 & Tsykun et al. (2013) \\
\hline & $\mathrm{A} 2$ & Finland & HQ232279 & HQ285901 & Tsykun et al. (2013) \\
\hline & A618 & Switzerland & JN657442 & JN657496 & Tsykun et al. (2013) \\
\hline & $\begin{array}{l}\text { CMW31075, } \\
\text { KK0124/1 }\end{array}$ & Belarus & KM205305 & KM205252 & This study \\
\hline \multirow[t]{5}{*}{ A. calvescens } & ST3 & Quebec, Canada & AY509163 & JF313138 & $\begin{array}{l}\text { Kim et al. (2006), Ross- } \\
\text { Davis et al. (2012) }\end{array}$ \\
\hline & ST17 & Michigan, USA & AY509164 & JF313130 & $\begin{array}{l}\text { Kim et al. (2006), Ross- } \\
\text { Davis et al. (2012) }\end{array}$ \\
\hline & ST18 & Michigan, USA & AY509166 & JF313129 & $\begin{array}{l}\text { Kim et al. (2006), Ross- } \\
\text { Davis et al. (2012) }\end{array}$ \\
\hline & $\begin{array}{l}\text { CMW31078, } \\
\text { KK3437/1 }\end{array}$ & USA & KM205307 & KM205254 & This study \\
\hline & $\begin{array}{l}\text { CMW31079, } \\
\text { KK3438/1 }\end{array}$ & USA & KM205308 & KM205255 & This study \\
\hline A. calvescens & $\begin{array}{l}\text { CMW31080, } \\
\text { KK3456/1 }\end{array}$ & USA & KM205309 & KM205256 & This study \\
\hline \multirow[t]{2}{*}{ A. cepistipes } & BRNM706814 & Czech Republic & EU257709 & EU251395 & Antonın et al. (2009) \\
\hline & SY1Ra & UK & JF288720 & JF746917 & Mulholland et al. (2012) \\
\hline
\end{tabular}




\begin{tabular}{|c|c|c|c|c|c|}
\hline Species & Isolate & Country & IGS & TEF-1 $\alpha$ & Reference $^{a}$ \\
\hline \multirow[t]{10}{*}{ A. cepistipes } & B2 & Finland & KJ414316 & KJ414319 & $\begin{array}{l}\text { Tsykun et al.(2013), Keča et } \\
\text { al. (2014) }\end{array}$ \\
\hline & EB3 & Finland & KJ414317 & KJ414320 & $\begin{array}{l}\text { Mulholland et al. (2012), } \\
\text { Keča et al. (2014) }\end{array}$ \\
\hline & B5 & Italy & KJ414318 & KJ414321 & $\begin{array}{l}\text { Tsykun et al. (2013), Keča et } \\
\text { al. (2014) }\end{array}$ \\
\hline & C13AE & Ukraine & JN657420 & JN657474 & Tsykun et al. (2013) \\
\hline & 94_46_01 & Fukushima, Japan & AB510849 & AB510793 & Hasegawa et al. (2010) \\
\hline & $90-10-12$ & Niigata, Japan & AB510818 & AB510790 & Hasegawa et al. (2010) \\
\hline & S20 & British Columbia, Canada & AY509183 & JF313116 & $\begin{array}{l}\text { Kim et al. (2006), Ross- } \\
\text { Davis et al. (2012) }\end{array}$ \\
\hline & W113 & Washington, USA & AY509184 & JF313115 & $\begin{array}{l}\text { Kim et al. (2006), Ross- } \\
\text { Davis et al. (2012) }\end{array}$ \\
\hline & $\begin{array}{l}\text { CMW31082, } \\
\text { KK9908/2 }\end{array}$ & Finland & KM205310 & KM205258 & This study \\
\hline & $\begin{array}{l}\text { CMW31083, } \\
\text { KK3160/2 }\end{array}$ & Italy & KM205311 & KM205258 & This study \\
\hline \multirow[t]{8}{*}{ A. gallica } & $86-016 / 3$ & Munchen, Germany & KJ200946 & KJ200952 & Keča et al. (2014) \\
\hline & $86-032 / 1$ & Iran & KJ200949 & KJ200955 & Keča et al. (2014) \\
\hline & Y7C-S1 & Ukraine & JN657431 & JN657485 & Tsykun et al. (2012) \\
\hline & E5 & France & JF288737 & JF746920 & Mullholland et al. (2012) \\
\hline & E6 & France & JN657426 & JN657480 & Tsykun et al. (2013) \\
\hline & HY2a & Ukraine & JN657428 & JN657482 & Tsykun et al. (2013) \\
\hline & NA13 & Japan & AB510842 & AB510760 & Hasegawa et al. (2010) \\
\hline & NA4 & Japan & AB510834 & AB510761 & Hasegawa et al. (2010) \\
\hline
\end{tabular}




\begin{tabular}{|c|c|c|c|c|c|}
\hline Species & Isolate & Country & IGS & TEF-1 $\alpha$ & Reference $^{a}$ \\
\hline \multirow[t]{6}{*}{ A. gallica } & M70 & British Columbia, Canada & AY509171 & JF313123 & $\begin{array}{l}\text { Kim et al. (2006), Ross- } \\
\text { Davis et al. (2012) }\end{array}$ \\
\hline & ST22 & Michigan, USA & AY509172 & JF313126 & $\begin{array}{l}\text { Kim et al. (2006), Ross- } \\
\text { Davis et al. (2012) }\end{array}$ \\
\hline & ST23 & Wisconsin, USA & AY509173 & JF313125 & $\begin{array}{l}\text { Kim et al. (2006), Ross- } \\
\text { Davis et al. (2012) }\end{array}$ \\
\hline & $\begin{array}{l}\text { CMW31086, } \\
\text { KK5298/2 }\end{array}$ & Russia & KM205312 & KM205259 & This study \\
\hline & $\begin{array}{l}\text { CMW31090, } \\
\text { KK8104/3 }\end{array}$ & Italy & KM205315 & KM205262 & This study \\
\hline & $\begin{array}{l}\text { CMW31091, } \\
\text { KK3090/2 }\end{array}$ & Italy & KM205316 & KM205263 & This study \\
\hline \multirow[t]{5}{*}{ A. gemina } & ST8 & New York, USA & AY509158 & JF313136 & $\begin{array}{l}\text { Kim et al. (2006), Ross- } \\
\text { Davis et al. (2012) }\end{array}$ \\
\hline & ST9 & New York, USA & AY509160 & JF313135 & $\begin{array}{l}\text { Kim et al. (2006), Ross- } \\
\text { Davis et al. (2012) }\end{array}$ \\
\hline & ST11 & West Virginia, USA & AY509162 & JF313133 & $\begin{array}{l}\text { Kim et al. (2006), Ross- } \\
\text { Davis et al. (2012) }\end{array}$ \\
\hline & $\begin{array}{l}\text { CMW31094, } \\
3443 / 1\end{array}$ & USA & KM205318 & KM205265 & This study \\
\hline & $\begin{array}{l}\text { CMW31095, } \\
\text { KK3454/1 }\end{array}$ & USA & KM205319 & KM205266 & This study \\
\hline \multirow[t]{5}{*}{ A. mellea } & D1 & France & JN657437 & JN657491 & Tsykun et al. (2013) \\
\hline & HY3 & Ukraine & JN657439 & JN657493 & Tsykun et al. (2013) \\
\hline & $94 \_5$ & Japan & AB510833 & AB510802 & Hasegawa et al. (2010) \\
\hline & A_12 & Japan & AB510820 & AB510801 & Hasegawa et al. (2010) \\
\hline & ST5 & Virginia, USA & AY509185 & JF313137 & $\begin{array}{l}\text { Kim et al. (2006), Ross- } \\
\text { Davis et al. (2012) }\end{array}$ \\
\hline
\end{tabular}




\begin{tabular}{|c|c|c|c|c|c|}
\hline Species & Isolate & Country & IGS & TEF-1 $\alpha$ & Reference $^{a}$ \\
\hline \multirow[t]{3}{*}{ A. mellea } & ST20 & Wisconsin, USA & AY509187 & JF313128 & $\begin{array}{l}\text { Kim et al. (2006), Ross- } \\
\text { Davis et al. (2012) }\end{array}$ \\
\hline & ST21 & New Hampshire, USA & AY509188 & JF313127 & $\begin{array}{l}\text { Kim et al. (2006), Ross- } \\
\text { Davis et al. (2012) }\end{array}$ \\
\hline & $\begin{array}{l}\text { CMW31171, } \\
\text { KK3441 }\end{array}$ & New Hampshire, USA & KM205321 & KM205268 & \\
\hline \multirow[t]{7}{*}{ A. nabsnona } & $\mathrm{C} 21$ & Idaho, USA & AY509174 & JF313119 & $\begin{array}{l}\text { Kim et al. (2006), Ross- } \\
\text { Davis et al. (2012) }\end{array}$ \\
\hline & M90 & British Columbia, Canada & AY509176 & JF313122 & $\begin{array}{l}\text { Kim et al. (2006), Ross- } \\
\text { Davis et al. (2012) }\end{array}$ \\
\hline & ST16 & Alaska, USA & AY509178 & JF313124 & $\begin{array}{l}\text { Kim et al. (2006), Ross- } \\
\text { Davis et al. (2012) }\end{array}$ \\
\hline & NB4 & Aomori, Japan & AB510851 & AB510764 & Hasegawa et al. (2010) \\
\hline & $00-3-1$ & Aomori, Japan & AB510850 & AB510766 & Hasegawa et al. (2010) \\
\hline & $\begin{array}{l}\text { CMW31100, } \\
\text { KK3458/1 }\end{array}$ & Canada & KM205323 & KM205270 & This study \\
\hline & $\begin{array}{l}\text { CMW31101, } \\
\text { KK3459/1 }\end{array}$ & USA & KM205324 & KM205271 & This study \\
\hline \multirow[t]{8}{*}{ A. solidipes } & BRNM 706815 & Czech Republic & EU257711 & EU251400 & Antonin et al.(2009) \\
\hline & $\mathrm{C} 5$ & France & HQ232281 & HQ285903 & Tsykun et al. (2013) \\
\hline & $\mathrm{C} 2$ & France & JN657432 & JN657486 & Tsykun et al. (2013) \\
\hline & HpAg1 & Ukraine & JN657435 & JN657489 & Tsykun et al. (2013) \\
\hline & NC8 & Aomori, Japan & AB510848 & AB510782 & Hasegawa et al. (2010) \\
\hline & 2002_66_03 & Tochigi, Japan & AB510847 & AB510781 & Hasegawa et al. (2010) \\
\hline & ST1 & New Hampshire, USA & AY509154 & JF313141 & $\begin{array}{l}\text { Kim et al. (2006), Ross- } \\
\text { Davis et al. (2012) }\end{array}$ \\
\hline & ST2 & Washington, USA & AY509155 & JF313139 & $\begin{array}{l}\text { Kim et al. (2006), Ross- } \\
\text { Davis et al. (2012) }\end{array}$ \\
\hline
\end{tabular}




\begin{tabular}{|c|c|c|c|c|c|}
\hline Species & Isolate & Country & IGS & TEF-1 $\alpha$ & Reference $^{a}$ \\
\hline \multirow[t]{2}{*}{ A. solidipes } & P1404 & Idaho, USA & AY509157 & JF313140 & $\begin{array}{l}\text { Kim et al. (2006), Ross- } \\
\text { Davis et al. (2012) }\end{array}$ \\
\hline & $\begin{array}{l}\text { CMW31107, } \\
\text { KK1066/3 }\end{array}$ & Finland & KM205328 & KM205275 & This study \\
\hline \multirow[t]{5}{*}{ A. sinapina } & M50 & British Columbia, Canada & AY509167 & JF313114 & $\begin{array}{l}\text { Kim et al. (2006), Ross- } \\
\text { Davis et al. (2012) }\end{array}$ \\
\hline & ST12 & Washington, USA & AY509168 & JF313132 & $\begin{array}{l}\text { Kim et al. (2006), Ross- } \\
\text { Davis et al. (2012) }\end{array}$ \\
\hline & ST13 & Michigan, USA & AY509169 & JF313131 & $\begin{array}{l}\text { Kim et al. (2006), Ross- } \\
\text { Davis et al. (2012 }\end{array}$ \\
\hline & $96-7-1$ & Hokkaido, Japan & AB510827 & AB510774 & Hasegawa et al. (2010) \\
\hline & $05-13-2$ & Hokkaido, Japan & AB510836 & AB510776 & Hasegawa et al. (2010) \\
\hline \multirow[t]{10}{*}{ A. tabescens } & HAt1S5 & Ukraine & HQ232284 & HQ285906 & Tsykun et al. (2013) \\
\hline & HAt2S5 & Ukraine & HQ232285 & HQ285907 & Tsykun et al. (2013) \\
\hline & HAt5S3 & Ukraine & HQ232286 & HQ285908 & Tsykun et al. (2013) \\
\hline & ET3 & France & JF288740 & JF746929 & Mulholland et al. (2012) \\
\hline & ET4 & France & JF288741 & JF746930 & Mulholland et al. (2012) \\
\hline & $96-3-3$ & Japan & AB510824 & AB510805 & Hasegawa et al. (2010) \\
\hline & $96-1-8$ & Japan & AB510823 & AB510804 & Hasegawa et al. (2010) \\
\hline & AT-MU-S2 & South Carolina, USA & AY509189 & JF313113 & $\begin{array}{l}\text { Kim et al. (2006), Ross- } \\
\text { Davis et al. (2012) }\end{array}$ \\
\hline & OOI-99 & Georgia, USA & AY509192 & JF313112 & $\begin{array}{l}\text { Kim et al. (2006), Ross- } \\
\text { Davis et al. (2012) }\end{array}$ \\
\hline & OOI-210 & Georgia, USA & AY509191 & JF313111 & $\begin{array}{l}\text { Kim et al. (2006), Ross- } \\
\text { Davis et al. (2012) }\end{array}$ \\
\hline
\end{tabular}


Supplementary Table S2 (continued)

\begin{tabular}{|c|c|c|c|c|c|}
\hline Species & Isolate & Country & IGS & TEF-1 $\alpha$ & Reference $^{a}$ \\
\hline \multirow[t]{2}{*}{ A. tabescens } & $\begin{array}{l}\text { CMW31119, } \\
\text { KK3380/1 }\end{array}$ & Italy & KM205334 & KM205281 & This study \\
\hline & $\begin{array}{l}\text { CMW31120, } \\
\text { KK9083/4 }\end{array}$ & Italy & KM205335 & KM205282 & This study \\
\hline \multirow[t]{3}{*}{ NAG E } & NE4 & Tottori, Japan & AB510828 & AB510771 & Hasegawa et al. (2010) \\
\hline & $94-2-1$ & Nagano, Japan & AB510840 & AB510768 & Hasegawa et al. (2010) \\
\hline & $96-37-1$ & Kanagawa, Japan & AB510845 & AB510769 & Hasegawa et al. (2010) \\
\hline A. singula & HUA9101 & Japan & D89926 & & Tersahima et al. (1998) \\
\hline A. jezoensis & HUA9116 & Japan & D89921 & & Tersahima et al. (1998) \\
\hline
\end{tabular}

a Antonín et al. (2009) Mycological Progress 8: 259-271.; Hasegawa et al. (2010) Mycologia 101: 898-910.; Keča et al. (2014) Forest Pathology: online; doi:10.1111/efp.12135.; Kim et al. (2006) Forest Pathology 36: 145-164.; Mulholland et al. (2012) Forest Pathology 42: 229-238.; Ross-Davis et al. (2012) Mycoscience 53: 161-165.; Terashima et al. (1998) European Journal of Forest Pathology 28: 11-19.; Tsykun et al. (2013) Mycologia 105: 1059-1076. 
Supplementary Table S3 - Data matrices and nucleotide substitution models employed in maximum likelihood and Bayesian analyses.

\begin{tabular}{|c|c|c|c|c|}
\hline Matrix & $\begin{array}{l}\text { Number of } \\
\text { characters }\end{array}$ & Model & $\begin{array}{l}\alpha \text { shape } \\
\text { parameter }\end{array}$ & $\begin{array}{l}\text { Portion of } \\
\text { invariable sites }\end{array}$ \\
\hline \multicolumn{5}{|c|}{ Armillaria tabescens dataset } \\
\hline IGS-1 & 608 & GTR+I & 0.1030 & \\
\hline TEF-1 $\alpha$ & 447 & TIM1ef $+\mathrm{G}$ & 0.2480 & \\
\hline \multicolumn{5}{|c|}{ Northern Hemisphere Armillaria phylogeny dataset } \\
\hline IGS-1 & 787 & $\mathrm{TVM}+\mathrm{G}$ & 0.9730 & \\
\hline TEF-1 $\alpha$ & 594 & TIM3ef $+\mathrm{G}$ & 0.8530 & 0.3850 \\
\hline
\end{tabular}

